\title{
Facies Characteristics, Depositional Environments and Sequences Stratigraphy of the Euphrates Formation in Hadetha Area, Western Iraq
}

\author{
Mohamed Fahad Al-Ghreri ${ }^{1}$, Salam Obied Al-Hetty ${ }^{2}$ and Amer Sadie Al-gibouri ${ }^{3}$ \\ Department of Appl. Geology Faculty of Science. Anbar University. \\ ${ }^{1}$ E-mail: d_alfahad1953@yahoo.com. \\ ${ }^{2}$ E-mail: salamobied55@yahho.com. \\ ${ }^{3}$ E-mail: aalgibouri@yahoo.com.
}

\begin{abstract}
The Euphrates Formation (Lower-early middle Miocene) shallow water carbonates, western Iraq was studied in order to determine its microfacies and depositional environment. According to the benthic foraminiferal assemblage along with other skeletal and non-skeletal components, Fourteen microfacies associations types (F1-F14) are recorded and distributed as: Lime mudstone, miliolids wackestone, alveolinids wackestone, echinoids wackestone, bioclastic packstone, peliods packstone, miliolids packstone, peneroplids packstone, rotaliids packstone, miliolids grainstone, peliods grainstone, ooids grainstone, miliolids-peneroplids grainstone, and peneroplids grainstone that were deposited in three facies belts, restricted marine, shoal, and open marine environments. Based on field observations, microfacies analysis and sequence stratigraphic concepts, the Lower Miocene successions is represented by four order cycles (A, B, C and D) they are mostly asymmetrical showing slightly lateral variation in thickness and symmetry. These cycles represent a succession episode of sea level rises and stillstands. The nature of these cycles reflects variation in the relative sea level resulted from eustatic and tectonic subsidence. Cycle A is underlain by Anah Formation, while cycle C is overlain by SB1 Fatha Formation. According to sequence development, the study area shows low rate of subsidence and the major controlling factor that effect is eustatic sea level fluctuation.
\end{abstract}

Keywords: Depositional environment, Sequences stratiqraphy, Microfacies analysis, Wadi Hajr, Iraq.

\section{Introduction}

The Euphrates Formation consists of marine carbonate rocks. It has wide exposures on the southern and western sides of the Euphrates River. It extends from Al-Qaim in the NW to Samawa in the SE, where it interfingers with and passes laterally to Ghar Formation [1]. The formation was divided into three units: A, B and C, from older to younger [2]. But, the Upper Unit (C) was found to be another formation, which was named as Nfayil Formation [3]. According to the variations in the lithologic characters, [4] divided the Euphrates Formation in Haditha - Hit vicinity into five units and eleven lithofacies. The aims of this study are microfacies analysis, reconstruction of sedimentary environment, describe and interpret the origin of sequences that developed in the study area mainly based on the distribution of the benthic foraminifera

\section{Previous studies}

The term "Euphrates Formation" was introduced by De Beockh in 1929 [5]. The thickness of the Euphrates Formation in the type locality is $8 \mathrm{~m} \mathrm{[5]} \mathrm{and} \mathrm{in} \mathrm{the}$ supplementary type section is $110 \mathrm{~m}$. In Haditha area is (55-87) $\mathrm{m}$ [6], mainly consist of shelly, chalky and well bedded recrystalized limestone and assigned it to "Lower" Miocene in age Fig.(1).

Recently [7] suggested another section at Al-Baghdadi area as a reference section, because the type section at wadi Fuhaimi submerged by the Al-Qaddisiyah lack. Ever since, many studies appeared for different aim, including those of; [8]; [9]; [10]; [4]; [11]; [12]; [13]; and off course, [7], [14] detailed all these studies. 


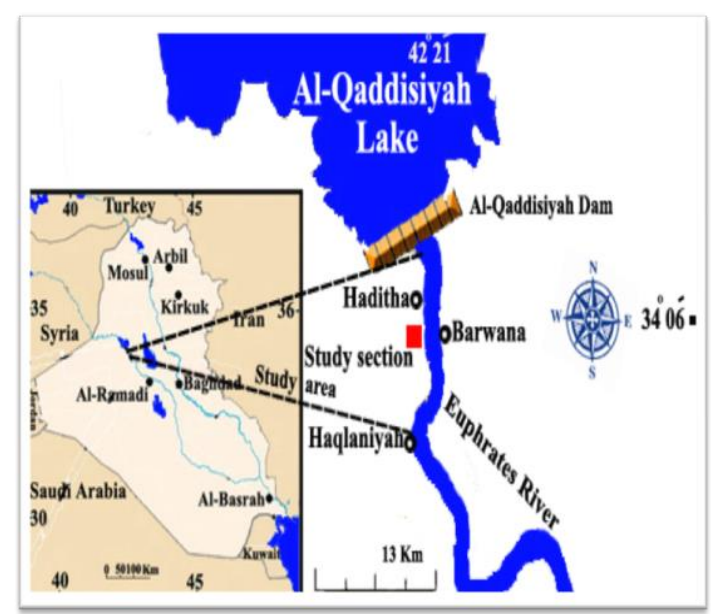

Fig.(1): Location of the study area in the western Iraq.

\section{Methodology}

From reviewing the described Euphrates Formation in the Iraqi Western Desert, it is clear that there are large facial changes, had led to different lithological constituents of the formation, in different areas. Twenty three samples were collected from the studied section (Wadi Hajr) in the type locality of the Euphrates Formation. Forty-two thin sections were prepared for petrographic and sedimentological analysis of the Euphrates carbonates. Definition of microfacies is based on depositional texture, grain size, grain and fossils content. Seventeen thin sections were treated with Alizarin Red-S and potassium ferricyanide to differentiate between limestone and dolostone facies.

\section{Stratigraphy}

In this study, Euphrates Formation composed of hard, crystalline, well bedded, massive highly fossiliferous limestone in the lower part, and white yellowish, chalky limestone interbedded with marly limestone in the upper parts. The lower contact of the Euphrates Formation is unconformable, underlying by Anah Formation and the upper contact is unconformable too, overlain by Fat'ha Formation that detected in this area.

According to the variations in the lithologic characters and the fossil content, the Euphrates Formation can be divided into two distinct units, lower and upper unit. The lower unit "basal conglomerates" layer contain reworked fossils [15], consist from grey, massive, hard, mainly crystalline, rich fossiliferous, with coralline algal. The upper unit "Limestone unit" can be subdivided in to lower part contains thick bedded to massive limestone, dolomitic limestone, highly fossiliferous with greenish white, chalky limestone interbedded with bluish green marl in the upper part.

The limestone of the Euphrates Formation yielded major components of benthic foraminifera such as, miliolids, peneroplids, alveolinids, rotaliids, echinoderms plates and non-clastic mainly ooids, peliods and micritized skeletal grains with less amount of the algae, molluscan and the skeletal debris particles are present.

According to its stratigraphical attitude and faunal content, the Euphrates Formation is assigned to the Miocene in age, this agrees with the opinions of [16]; [17]; [18].

\section{Microfacies studies}

In the present study, the limestone microfacies are described and differentiated using the classification [19] with the modification of [20]. Four main microfacies association types have been recognized: mudstone, wackestone, packstone and grainstone. Each of them is subdivided into several subtypes, thus in total 14 microfacies types are recorded and distributed in Euphrates Formation. These microfacies enabled the recognition of three major environments (restricted marine, shoal and open marine), which represent the following facies associations:

\subsection{Restricted marine environment. \\ 5.1.1 Lime mudstone microfacies (MF1)}

The term "lime mudstone" is used here to describe the mud-supported limestone which is composed mainly composed of $90 \%$ to $100 \%$ of lime mud, with fossil fragments range from $1-9 \%$ of the rock [25]. This facies covered the basal conglomerate layer, and it is reported in the 'limestone units, recorded in four horizons with different thickness ranges from (0.20$0.70 \mathrm{~m}$ ). As well as, this microfacies also recorded in the rocks of the upper parts of the upper unit with an average thickness ranges from (4-5m), represented by white chalky, fine-grained, poorly fossiliferous limestone, interbedded with marl. Fig.(2-A).

Petrographically, the lime mudstone is mainly composed of micrite and microspars 
created by the aggrading neomorphism. The allochems form about up to $9 \%$ of the rock and they are represented by randomly distributed skeletal particles of bioclasts (up to 6\%) of foraminifera, green algae, molluscs. These allochems are commonly recrystallized to sparry calcite crystals.

This facies was deposited in a restricted marine shelf lagoon environment [21].

\subsection{Shoal Environment}

\subsubsection{Peloids grainstone microfacies (MF2)}

In the field, the rock is grey, cavernous, massive, and very hard in the lower parts, burrowed limestone in the upper parts. The peloidal grainstone is occurring in one bed throughout the upper section, with average thickness of about $1.5 \mathrm{~m}$.

In thin sections, Peloids are small in size, subspherical to ovoidal in shape, conspicuously rounded, and well sorted. They don't exhibit any evident structure or organization such as gradation or lamination. The main components are peloids (76\%), ooids $(8 \%)$ and sparry calcite cement $(7 \%)$, miliolids (5\%), rotaliids (2\%). Fig.(3-E).

The peloidal facies is usually common in the shallow marine protected, low energy, back-bank lagoonal environments [22]. While the peloidal packstone to grainstone facies was recorded from the lagoonal carbonate sediments [23]. Moreover the abundance of peloids, intraclasts and matrix and lack of subareial exposure feature suggests a low energy, restricted subtidal lower intertidal environment deposition [24]. While [25] revealed that the fecal pellets are a dominant constituent of the recent subtidal and shallow marine intertidal settings with only moderate water circulation.

\subsubsection{Ooids grainstone microfacies (MF3)}

The ooids grainstone is considered as one of the most distinct microfacies of the middleupper section in horizontal bedded limestone with an average thickness of $2 \mathrm{~m}$. In thin sections, the most important allochemcial grains are ooids $(75 \%)$, peliods $(12 \%)$, small benthic foraminifera (2\%), and shell fragments less than of $1 \%$. The ooids present are mainly normal ooids, well sorted, small with multiple concentric laminates and exhibit distinct tangential microstructures type, some of them are micritized and a few are dissolved. Fig.(3-F).

[26] suggests that its formations are primarily in equatorial area, in environment with active currents. And also revealed that the best environments for ooids formation are tidal deltas and bars, or beaches (marine or lacustrine) where superficial grains are kept in daily motion. Throughout this facies, compound ooids appear, it is uniformly arranged and forming what is called "grapestone" [27].
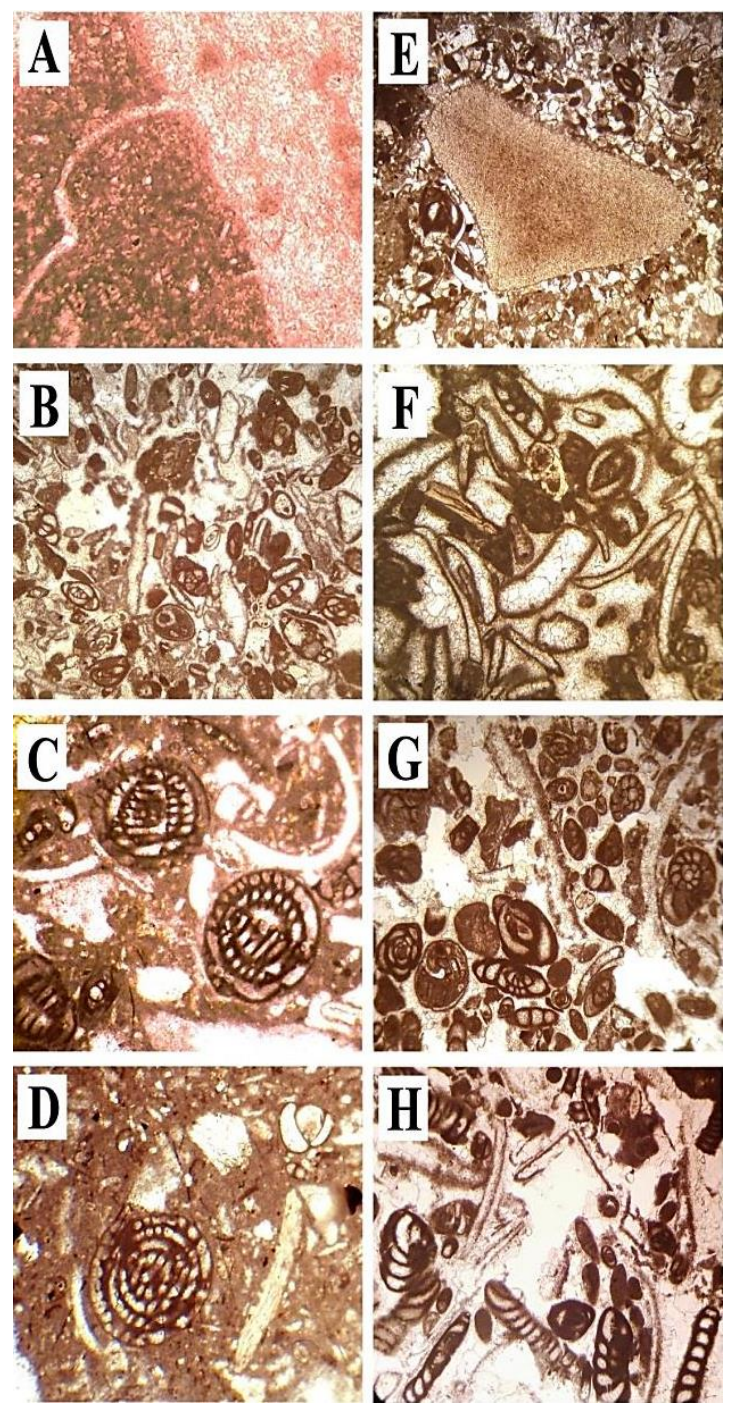

Fig.(2): Microfacies types (MF) of The Euphrates Formation:

A- Lime mudstone microfacies X 45 (MF1).

$B$ - Miliolids wackestone microfacies X 35 (MF2).

$C, D$ - Alveolinids wackestone microfacies $X$ 60(MF3).

E- Echinoids wackestone microfacies X $60($ MF4).

F-Bioclastic Packstone microfacies X 45(MF5).

$G$ - Miliolids packstone microfacies X 35(MF6).

H- Peneroplids packstone microfacies $X \quad 45$ (MF7). 

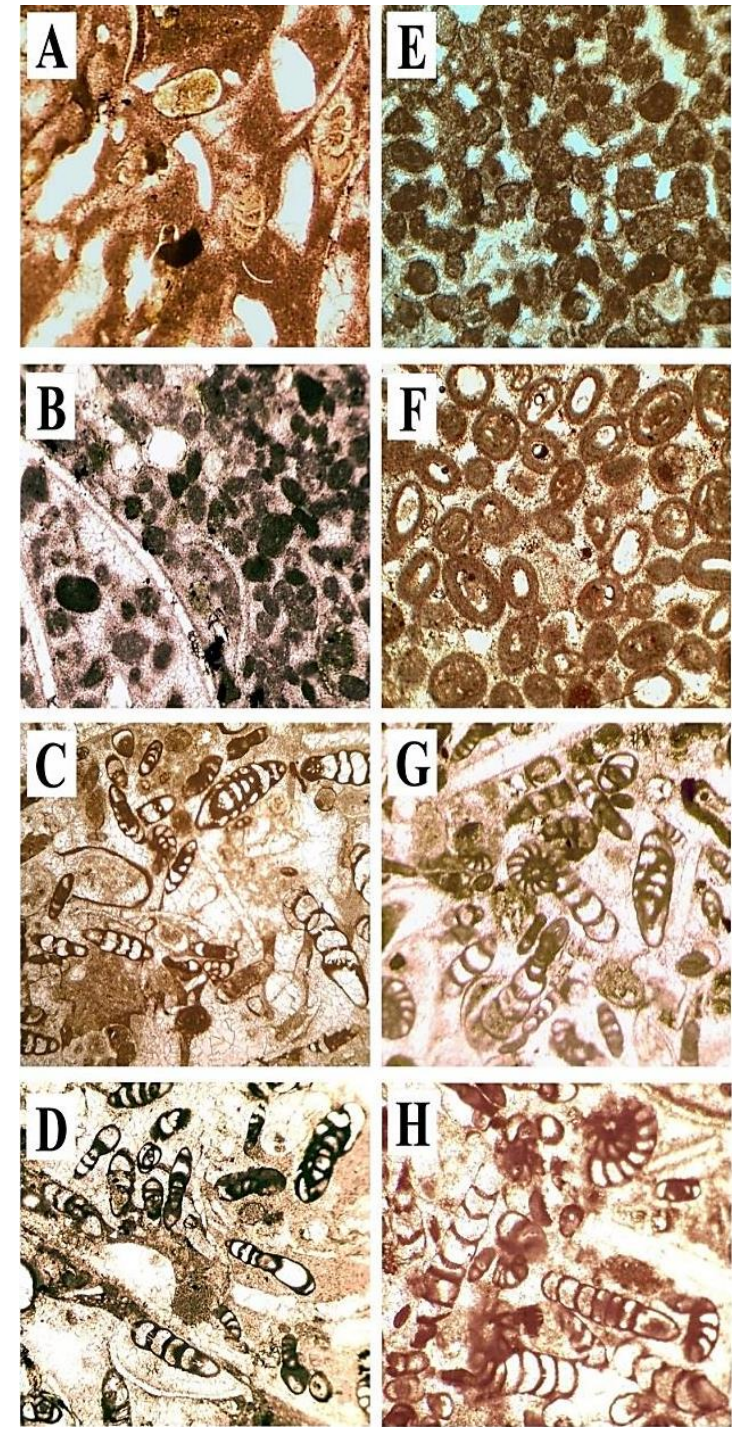

Fig.(3): Microfacies types (MF) of The Euphrates Formation:

A- Rotaliids packstone microfacies X 60(MF8)

$B$-Peloids packstone microfacies X45(MF9)

$C, D$ - Miliolids grainstone microfacies $X 45$ (MF 10)

E- Peloids grainstone microfacies X 35 (MF11)

$F$-Ooids grainstone microfacies $X$ 60(MF12)

$G$ - Miliolids-Peneroplids grainstone microfacies X 60 (MF13)

H-Peneroplids grainstone microfacies X 60(MF1

\subsubsection{Miliolids grainstone microfacies (MF4)}

The main components of this facies include benthic foraminifera mainly (Dendritina sp. and Peneroplis sp. all this biota grains are good sorted. Dendritina rangi D'orbigny are dominantly grainstone (60\%), Peneroplis sp. (5), and Quinqueloculina sp. (3\%) with less amounts of algae (2\%), but this microfacies range from packstone to grainstone in some time. Fig.(3-C,D).
This facies has been deposited in tropical neritic environment of open lagoon (back-reef) down the middle reef slop less than $40 \mathrm{~m}$. Contain mollusca and algae debris [36] a restricted shelf lagoon [29]. This microfacies represents the shallowest upper part of the photic zone, with very light, highly translucent and soft muddy substrate [30]; [31]. As well as, the presence of well-sorted grains and lack of mud indicate high-energy conditions [32]; [26].

\subsubsection{Miliolids - Peneroplids grainstone microfacies (MF5)}

This microfacies are limited in one bed at the middle-upper part of the Euphrates Formation, with a thickness of about $1.5 \mathrm{~m}$. In thin sections, It was found the most common foraminiferal particles representing miliolids (Quinqueloculina, Triloculina, pyrgo) more than $(32 \%)$ of this facies, besides, peneroplids (22\%) small rotaliids (3-5\%), ooids (2\%) and peliods less than (2\%). Fig.(3-G).

This microfacies consists mainly of skeletal particles and sparry calcite as cement. Furthermore, as said above, the miliolids are the main component of skeletal particles, so that, the binding material between the skeletal particles is sparry calcite cement, the omnipresence of sparry calcite cement is an indication of strong currents capable of removing clay particles, thus creating passage ways for solution that deposited the cements.

\subsubsection{Peneroplids grainstone microfacies (MF6)}

This microfacies occurs mainly in the upper part of wadi Hajr section, consist mainly of imperforate benthic foraminifera such as Peneroplis farsensis more than (30\%), Spirolina sp. (12), Dendritina sp. (8\%), peloids $(4 \%)$ bryoza $(2 \%)$ and less than of shell fragments. Fig.(3-H).

Recent peneroplids and soritids mainly live in shallow-water, low-energy areas [33]. The occurrence of large number of imperforate foraminifera test indicates that the sedimentation took place in a shelf lagoon setting [30]. 


\subsection{Open marine environment}

\subsubsection{Echinoids wackestone microfacies (MF7)}

This microfacies is recorded in the midupper part of wadi Hajr, with a thickness of $(1.5 \mathrm{~m})$. The rock is represented by chalky, grey to white and porous, cavernous fossiliferous limestone. In thin section, the rock consists of echinoids plates (12\%), miliolids $(5 \%)$, peneroplids $(4 \%)$, rotaliids (2-3\%), echinoids fragments (1-2) and less (1) intraclasts. Fig.(2-E).

This microfacies include different textures ranging from wackestone to packstone. The presence of echinoderm plates and in this facies indicates normal marine conditions, and suggested that these sediments were deposited in moderate to low energy whilst muddy fabric indicates low energy conditions. [34].

\subsubsection{Miliolids wackestone microfacies (MF8)}

This microfacies is observed in the lower and middle parts of the limestone units, it is underlain by the echinoids wackestone and overlain by the peloidal packstone. The rock is gray to white, hard, crystalline, burrowed and thin laminated. Under the microscope (thinsections), presence mainly of miliolids (27\%), peneroplids (13\%), molluscs $(3 \%)$, in addition to shell fragments less than (2\%). Fig.(2-B).

The occurrence of miliolids and peneroplids live in restricted lagoon conditions [29];[30]. Furthermore, this facies deposited in low energy restricted/lagoon environments, as indicated by low diversity skeletal fauna, lack of subareial exposure and the stratigraphic position. [25], where grate fluctuations in salinity and temperature probably occurred.

\subsubsection{Alveolinids wackestone microfacies (MF9)}

Alveolinids wackestone is represented in the upper part overlain by lime mudstone with an average thickness of (5) $\mathrm{m}$. Petrography, the rock is fossiliferous, white to brown limestone with chalky limestone, highly burrowed in the upper part.

The main components benthic foraminifera mainly by alveolinids Ammonia beccarii (15\%), miliolids (6\%), Elphidium sp. (4\%), echinoids plates (3) and intraclasts less than
(2\%) with fewer amounts of skeletal particles scattered throughout a micritic matrix. The occurrence of benthic foraminifera with porcelaneous (miliolids and alveolinids), shows the environments with very limited circulation and relatively hypersaline [38]. This facies represents shallow water setting with low turbidity, highlight intensity and lowsubstrate stability, within the upper part of the photic zone [35], [36]. Fig.(2-C,D).

The occurrence of miliolids, Elphidium spp., and Ammonia spp., all of which are common in back-barrier environments. Foraminiferal assemblages also suggest that early back-barrier sediments were deposited in a hypersaline environment [37]. According to [33], Alveolinids are important faunal contributors to open water sediment of the inner platform. Furthermore, this microfacies occur in shallow marine inner shelf open lagoons-restricted circulations [32].

\subsubsection{Peloids packstone microfacies (MF10)}

This microfacies occurred in two horizons (lower and middle parts of formation) overlain by miliolids wackestone and miliolids grainstone. The rocks are formed of whitish grey to white, crystalline and burrowed fossiliferous limestone, overlain by fossiliferous limestone.

In thin sections, the peloids found here are rounded, elliptical or irregular forms, consist of mainly of fecal peloids, which caused by micritization of the grains or pellets caused breaking and coalescence of clays [24]. While [25] revealed that the fecal pellets are a dominant constituent of the recent subtidal and shallow marine intertidal settings of low energy water. As well as, the fecal peloids and micritized grains are the most abundant allochemical grains where they form about $38 \%$ of the rock. Other components are miliolids (6\%), peneroplids (3\%), molluscs $(2.5 \%)$, algae $(1.5 \%)$ and less than $(1 \%)$ fragments echinoidal plates. Fig.(3-B).

\subsubsection{Bioclastic Packstone microfacies (MF11)}

In this study, bioclastic microfacies usually occurs in two beds at the lower and the middle parts, range in thickness between $1 \mathrm{~m}$ and $1.5 \mathrm{~m}$, overlies the peloidal packstone in the 
lower parts and mudstone microfacies in the upper parts.

Petrography, the rock is white to gray, fossiliferous limestone. In thin sections, it is composed of bioclasts (42\%), peloids (12\%), rotaliids $(6 \%)$, peneroplids $(6 \%)$, miliolids ( $4 \%)$, algae $(2.5 \%)$, bryozoa ( $2 \%)$, gastropods $(2 \%)$ and ostracods less than (1\%). Fig.(2- F).

\subsubsection{Peneroplids packstone microfacies (MF12)}

This microfacies occurs in the lower and the middle-upper part of the section with total thickness of $4 \mathrm{~m}$ overlain by rotaliids packstone. The main components of this facies are peneroplids (42\%) mainly (Peneroplis farsensis, Peneroplis evolutus, Peneroplis sp.), miliolids (14\%), Rotaliids $(6 \%)$ and other components less than $(2 \%)$ of shell fragments. Fig.(2-H).

This microfacies is affected by micritization. [16] mentions that infilling submicrofacies of peneroplids bearing wackestone-packstone with clay lumps, due to recrystalization and dolomitization. Environmentally, [38] concluded that all the peneroplidae including the genus Peneroplis prefer to live in shallow marine, mainly attached to near shore weeds as in case in Qatar (Arabian Gulf), [39] supported this view, peneroplis lives on sea weeds in environment of little sedimentation.

\subsubsection{Rotaliids packstone microfacies (MF13)}

This microfacies are overlies peneroplids packstone and overlain by lime-mudstone consists mainly of rotaliids (25\%), miliolids (18\%), peneroplids (10\%), alveolinids spp. $(5 \%)$, molluscs $(2 \%)$ and less than $(1 \%)$ fragments of algae. Fig.(3-A).

All rotaliids including the species Ammonia beccarii made its first appearance in the late Miocene. Ammonia sp. is wide spread in near shore marine environments, but given the patchy distribution of most shallow water foraminifera [40].

The occurrence of large number of benthic foraminiferal such as, Ammonia beccarii, Rotalia umbonata with miliolids and bivalve debris, may point to the depositional environment being slightly hyper-saline, and such an assemblage described to be associated with an inner ramp environment [32]; [25];[26].

\subsubsection{Miliolids packstone microfacies (MF14)}

This microfacies is recorded in one bed in the middle part with a thickness of $2 \mathrm{~m}$ overlain by miliolids grainstone facies. The rock is white, massive, compact and burrowed. In thin section, this microfacies is made up of miliolids such as, Quinqueloculina sp., Triloculina sp., Dendritina sp., (48\%), Peneroplids, Peneroplis sp. (8\%), Rotaliids, Ammonia beccarii sp. (5\%), fossil algae (2\%), Bryozoa (1.2\%) and micritized grains (1\%). Fig.(2-G).

The diverse and abundant miliolids represent restricted environments, which are common in back reef lagoon and sheltered area on the reef banks and this phenomenon is particularly true for Quinqueloculina sp. and Triloculina sp. which are somewhat euryhaline and should be common under such conditions [41]. The occurrence of a large number of imperforate tests indicates that the sedimentation took place in a shelf lagoon setting, inner ramp [30].

[42] asserted that high diversification and the greater numbers of miliolids species are indicative of lagoonal or back-reef environments in tropical shallow, clean waters of normal salinity. [43] stated that the miliolids occur in shallow water of barrier-reef lagoons, while [32] regarded that the most common miliolids representing the shallow, restricted lagoon environments.

\section{Sequence Stratigraphy}

Four fourth-order cycles were recognized in the Euphrates Formation section wadi Hajr Fig.(4). The assertion that they represent fourth order cycles depends on the time spam (0.1-1.0my) of the studied succession. These cycles are usually asymmetrical, they represent successive episode of sea level rise and stillstands. They are also bounded at bottom and top by Type-1 sequence boundary (SB1). Cycle A consist LST facies represented by basal conglomerate followed by along episode of sea level rise, where a thick succession of open marine facies of TST, followed by short 
episode of stillstand where thin succession of restricted marine facies of HST. This cycle is underlain by SB1 of Anah Formation Fig.(4). Cycle B is almost asymmetrical and its TST consisting of bioclastic, miliolidal, peloidal wackestone-packstone. Followed by thin HST consisting restricted marine facies. Cycle B is subdivided into $\mathrm{B} 1, \mathrm{~B} 2, \mathrm{~B} 3$, according to the minor eustatic fluctuation represented by restricted marine facies, while B2 is symmetrical where the TST of open marine facies followed by shoal facies of HST. B3 consisting of peloidal packstone facies (TST) overlain by short episode of HST (restricted marine facies). Asymmetrical cycle $\mathrm{C}$ overlies cycle $\mathrm{B}$ and consist of short episode of sea level rise of TST followed by long episode of sea level stillstand. Cycle $\mathrm{C}$ can be divided into $\mathrm{C} 1$ and $\mathrm{C} 2$. $\mathrm{C} 1$ consisting TST of bioclastic facies followed by HST of shoal facies. C2 represented by long episode of sea level rise of open marine facies overlain by short episode of sea level stillstand. Cycle D is symmetrical reflecting a balanced situation, where the transgressive system tract (TST) open marine facies followed by restricted marine facies of high stand system tract (HST). This cycle is overlain by type one sequence boundary SB1 of Fatha Formation.

The study area which is of low rate of subsidence represented by short episode of HST, on the other hand the eustatic sea level is the major controlling factors that effect in the exposed Euphrates sequence development [14].

\section{Summary and Conclusions}

Euphrates Formation in wadi Hajr area, west Iraq, composed of hard, crystalline, and well bedded massive limestone, burrowed in the lower and upper parts, and chalky limestone interbedded with yellowish-greenish marl in the upper parts which overlies by hard, massive undulation bands of silicified limestone equivalent to Fat'ha Formation. According to the lithologic variation and fossil content, Euphrates Formation can be subdivided into two units: the lower and upper units.

Microfacies analysis of the Euphrates Formation in the study area divided into twelve microfacies that is: lime mudstone, wackestone (two microfacies associations), packstone (five microfacies associations) and lime grainstone (three microfacies associations). It's very rich in miliolids, peneroplids, rotaliids, ooide and peloidal grains (fecal pellets and micritized skeletal grains) and contains appreciable amounts of the echinodermal, molluscan and skeletal debris particles. Based on field observations, a microfacies analysis and sequence stratigraphic concept, the Euphrates succession was deposited in an area of low rate of subsidence, where the major controlling factor is eustacy. Four fourth-order cycles can be recognized ( $\mathrm{A}, \mathrm{B}, \mathrm{C}$ and $\mathrm{D})$. Cycle $\mathrm{A}$ is represented by LST of basal conglomerate followed by long episode of sea level rise, where a thick succession of open marine facies of TST, followed by short episode of stillstand. Cycle B is subdivided into B1, B2, and $\mathrm{B} 3$, according to minor sea level changes, consisting of bioclastic, miliolids, peloids wackestone-packstone (TST), Followed by thin HST consisting restricted marine facies. Cycle C consisting of short episode of sea level rise of TST followed by long episode of sea level stillstand and subdivided into $\mathrm{C} 1$ and C2. Cycle D shows open marine facies (TST), followed by restricted marine facies of high stand system tract (HST). 
Mohamed Fahad Al-Ghreri

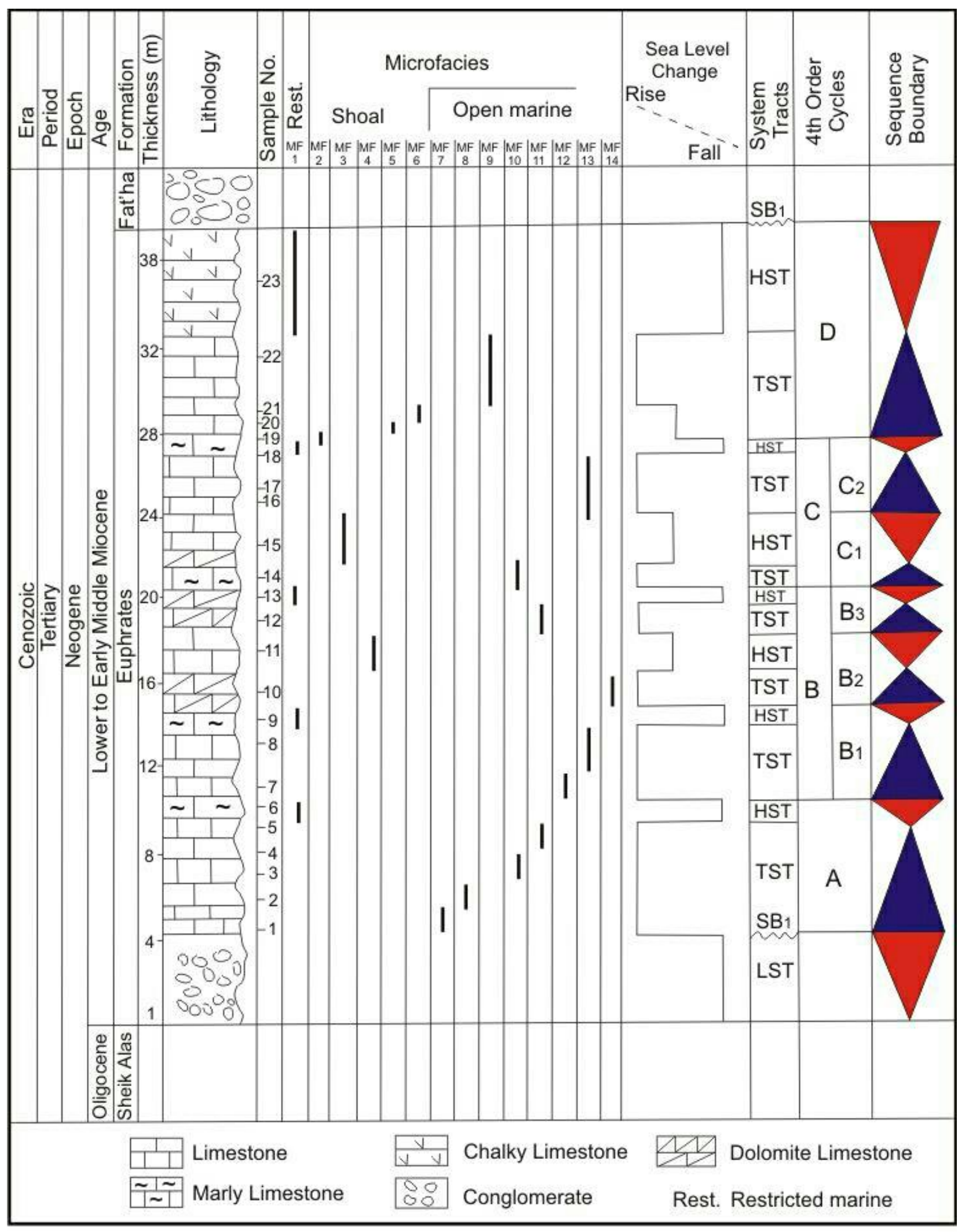

Fig.(4): Microfacies distribution and sequence stratigraphy of Euphrates formation at

Wadi-Hjar section. 


\section{References}

[1] Sissakian V.K, and Mohammed B.S. "Geology of Iraqi Western Desert", Iraqi Bulletin Geology Mining. 51-124, 2007.

[2] Al-Mubarak M. "The regional geological mapping of upper Euphrates valley", GEOSURV, internal report. no. 673, 1974.

[3] Sissakian V. K, Mahdi AI, Amin RM, Salman BM. "The Nfayil formation: a new lithostratigraphic unit in the Western Desert of Iraq". Iraqi Geological Journal. 30(1):61-65., 1997.

[4] Mahdi A.H.I., Sissakian V.K., Amin R.M., Salman B.S. and Hassan F.A. "Geological report on Hadetha area, part 1". GEOSURV, internal report. no1523., 1985.

[5] Van-Bellen R.C, Dunnington H.V., Wetzel R. and Mortion D.M. "Lexique stratigraphique International". III. Asie. In L. Dubetret (eds.), fasc. 10c. Iraq, Center Nat. Researche Scientifique", Paris 333p., 1959.

[6] Tyracek J. and Youbert Y. "Report on the regional geological survey of Western Desert between T1 Oil pumping station and wadi Hauran",GEOSURV, internal report. no. $673,1975$.

7] Al-Ghreri M.F., Sayyab A.S. and Jassim J.A. "Remarks on the age of the Miocene Euphrates formation, Western Iraq". Proceeding of the Fifth Scientific Environmental Conference. Zagazig University, Egypt. 185-195., 2010.

[8] Al-Dabbas M. "Facies analysis and geochemistry of Euphrates Formation, Central Iraq". Arab Journal of Geosciences, V. 7, 1799-1810., 2014.

[9] Buday T. "The regional geology of Iraq, Stratigraphy and paleogeography", State Organization for Minerals. Baghdad, Iraq. 1: 445 p., 1980.

[10] Al-Mubarak M. and Amin R.M. "Report on the regional geological mapping of the eastern part of the Western Desert and western part of the Southern Desert". GEOSURV internal report no. 1380., 1983.

[11] Sissakian V.K. "The geology of Hadetha Quadrangle, scale 1:250,000”. GEOSURV, Baghdad, Iraq., 1994.

[12] Al-Azzawi A.M. and Dawood R.M. "Report on detailed geological survey in northwest of Kilo 160-Rutbah area". GEOSURV, internal report no. 2491., 1996.

[13] Al-Bassam K. S., Mahdi M. A. and Al-Delaimi M. R. "contribution to the origin of the systematic uranium enrichment in the early Miocene carbonates of the Euphrates Formation", Iraqi Bulletin of geology and mining. Iraq. 2 (2): 1-23., 2006.

[14] Al-Ghreri M. F., Al-Jibouri A.S. and Al-Ahmed A.A, "Facies architecture and sequence development of the Euphrates formation in western Iraq", Arabian Journal of Geosciences. DOI 10.1007/s12517-0130944-z. 2013.

[15] Al-Ghreri M.F. and Al-Bakkal K. K. "Sedimentological and paleontological study of Oligocene-Miocene boundary basal conglomerates unit in west Iraq". Journal of Science Nature 2(1):22-27., 1993.

[16] Sayyab A. S., Jassim A. J. and Al-Ghreri M.F. "Biostratigraphy of the Euphrates formation (Early Lower Miocene-Middle Miocene) in its type locality". Journal of Geology Society. Iraq. 21 (2): 12-27., 1988

[17] Abid A.A. "Biostratigraphy and Microfacies of the Late Oligocene-Middle Miocene formations, Central and North Iraq". Unpublished $\mathrm{PhD}$ thesis, University of Baghdad, Iraq, 258 p. 1997.

[18] Al-Ghreri M. F. "Biostratigraphic succession of the formations of Euphrates valley between Hit and Al-Qaim in Iraq", $\mathrm{PhD}$ thesis, University of Baghdad, Iraq. 121 p., 2007.

[19] Dunham R. J. "Classification of carbonate rocks according to depositional texture", In: Ham, W. E. (Ed.). Classification of carbonate rocks: American Association of Petroleum Geologists Memoir 1: 108121.19, 873-900., 1962.

[20] Embry A. F. and Klovan J. E. "A late Devonian reef tract on northeastern Banks Islands, Northwest Territories", Bulletin Can Petroleum Geology 19:730-781., 1971.

[21] Wilson M. E.J. and Evans M.E.J. "Sedimentology and diagenesis of Tertiary carbonates on the Mangkalihat Peninsula", Boreneo: implications for subsurface reservoir quality. Marine and Petroleum Geology 19, 873-900., 2002. 
[22] Gischler E. "Holocene lagoonal development in the isolated carbonate platform off Belize", Sedimentary Geology 159(1-2):113-132., 2003.

[23] Evans K., Rowell A.J and Rees M. N. "Sea-level changes and Stratigraphy of the Nelson limestone (Middle Cambrian)", Neptune range, Antarctica. Journal of Sedimentary Research 65(1):32-43., 1995.

[24] Bathurst R.G.C. "Carbonate sediments and their diagenesis. Developments in Sedimentology", 12 : $2^{\text {nd }} . \quad$ Elsevier, Amsterdam. 658 p., 1975.

[25] Flügel E. "Microfacies analysis of limestones", Translated by K. Christenson. Springer, Berlin, 633 p., 1982.

[26] Flügel E. "Microfacies of carbonate rocks. Analysis interpretation and application", Springer, Berlin 976 p., 2004.

[27] Scholle A., and Ulmer-Scholle D.S. "A color guide to the petrography of carbonate rocks: grain, texture, porosity, digenesis", American Association of Petroleum Geologists Memoir. 77: 474 p., 2003.

[28] Reiss Z. and Hottinger L. "The Gulf of Aqaba", Ecological Micropaleontology. Berlin, Springer-Verlag. 354 p., 1984.

[29] Hallock P. and Glenn E.C. "Larger foraminifera: A tool for Paleoenvironmental analysis of Cenozoic carbonate depositional facies", Palaios 1: 55-64., 1986.

[30] Geel T. "Recognition of stratigraphic sequences in carbonate platform and slope deposits: empirical models based on microfacies analysis of Palaeogene deposits in southeastern Spain", Palaeogeography, Palaeoclimatology, 155:211-238., 2000.

[31] Bassi D., Hottinger L. and Nebelsick H. "Larger Foraminifera from the Upper Oligocene of the Venetian area, northeast Italy", Paleontology. 5(4): 845-868., 2007.

[32] Wilson J. L. "Carbonate facies in geologic history", Berlin, Heidelberg, New York, Springer. 471 p., 1975.

[33] Hottinger L. "Shallow benthic foraminiferal assemblages as signals for depth of their deposition and their limitations", Bulletin. Society. Geology. 168(4):491-505. 1997.,
[34] Multer H. G. "Field guide to some carbonate rock environments", Florida keys and western Bahamas 415p., 1977.

[35] Barattolo F., Bassi D. and Romero R. "Upper Eocene larger foraminiferalcoralline algal facies from the Klokova Mountain (south continental Greece)", Facies. 53: 361-375., 2007.

[36] Sadeghi R., Vaziri-Moghaddam H. and Taheri A. "Biostratigraphy and paleoecology of the Oligo-Miocene succession in Fars and Khuzestan areas (Zagros Basin, SW Iran)". Hist Biol. http:// www.informaworld.com/smpp/title*content $=$ t713717695., 2009 .

[37] Hill M. T. Brooks G. R. Duncan D. S. and Medioli F. S. "Benthic foraminifera of the Holocene transgressive west-central Florida inner shelf'. paleoenvironmental implications. Marine Geology 200. pp.263272., 2003,

[38] Bandy O.L. "Distribution of foraminifera, radiolarian and diatoms in sediments of the Gulf of California". Journal of Micropaleontology. 7(1):1-26, 1961.

[39] Murray J. W. "Living foraminifera in northern Florida Keys". American Association Petroleum Geology Bulletin. 41(4):727-741., 1968.

[40] Murray J.W., "Ecology and paleoecology of benthic foraminifera", Wiley, London 397 p., 1991.

[41] Ghose B. K., "Paleoecology of the Cenozoic reefal foraminifers and algae-a brief review", Palaeogeogr Palaeoclimatology Palaeoecology 22:231256., 1977.

[42] Brasier D. "Ecology of Recent sedimentdwelling and phyla foraminifera from lagoons of Barbuda, West Indies", Journal of Foraminiferal Research 5: 42-62. 1975a.

[43] Henson F. R. S., "Middle Eastern Tertiary Peneroplidae (Foraminifera) with remarks on the phylogeny and taxonomy of the family" PhD thesis, Leiden (Wakefield), England, 70 p., 1950. 


\section{الخلاصة}

الترسيب والتتابعية الطبقية. بالأعتماد على مجاميع

الفورامنيفيرا القاعية جنبا الى جنب مع المكونات الهيكلية

وغير الهيكلية تم تحديد (ع ا) اربع عشرة سحنة مجهرية

والتي ترسبت في البيئة البحرية الضحلة المفتوحة

والضحضاحه والبيئة البحرية الضحلة المحصورة. من خلال

الملاحظات الميدانية وبيئة الترسيب ومفاهيم التتابعية الطباقية

تم تحديد اربع دورات ترسيبية ذات المرتبة الرابعة

عكست العلاقة بين التغيرات في مستوى سطح

البحر. ان الأختلاف في تاثير العوامل الرئيسيه (مستوى

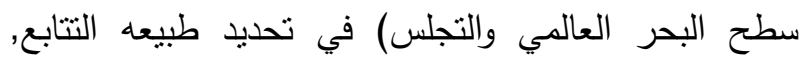
انعكس في اختلاف طبيعه نعاقب السحنات وسمك وتتاظر الدورات الترسيبيه, فقد ظهرت الدراسة بأن التجلس البطئ

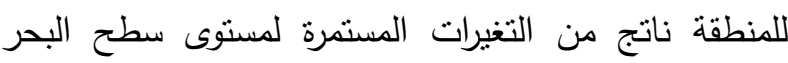

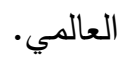

